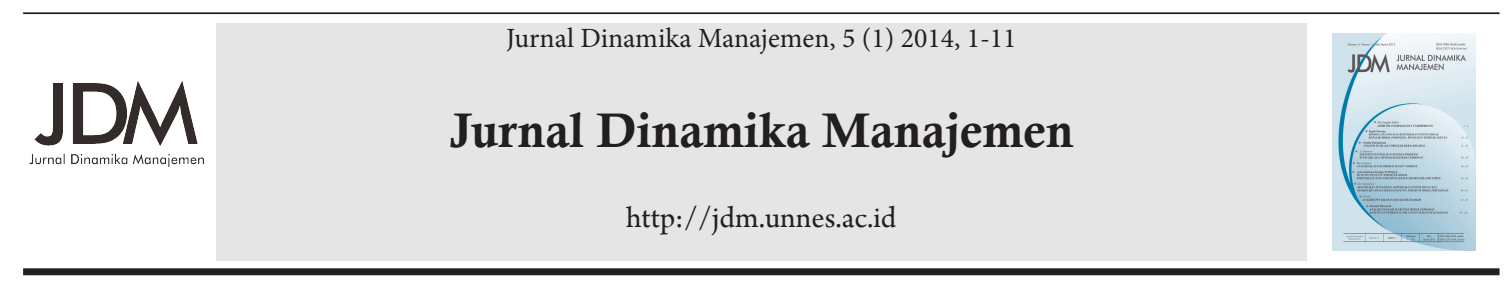

\title{
PROFESSIONAL BEHAVIOR BASED ON THE EMPLOYEES DEVELOPMENT
}

\section{Ketut Sudarma}

Faculty of Economics, Universitas Negeri Semarang, Semarang, Indonesia

\begin{tabular}{l} 
Info Artikel \\
\hline Sejarah Artikel: \\
Diterima Januari 2014 \\
Disetujui Januari 2014 \\
Dipublikasikan Maret 2014 \\
\hline Keywords: \\
development of work discipline; \\
professional behavior \\
profession ethics; \\
career. \\
\hline
\end{tabular}

\begin{abstract}
The objective of the study was to analyze the impact of work discipline management, career management and profession ethics management toward Unnes staff's beha-vior. The samples were taken by proportional random sampling. The variables of the research were work discipline management, career management, profession ethics management and professional behavior. The data were analyzed by multiple regression analysis. The result of this study showed that discipline work management, career management and profession ethics management gave positive influence toward staff's professional behavior. Furthermore, the result of percentage descriptive ana-lysis showed that the average of work discipline management, career management, profession ethics management and professional behavior were on enough category.
\end{abstract}

\section{PERILAKU PROFESIONAL BERBASIS PEMBINAAN PEGAWAI}

\begin{abstract}
Abstrak
Tujuan penelitian ini adalah menganalisis dampak pembinaan disiplin kerja, pembinaan karir dan pembinaan etika profesi terhadap perilaku profesional tenaga kependidikan Sampel 50 orang tenaga kependidikan Unnes. Teknik pengambilan sampel menggunakan proporsional random sampling. Variabel penelitian adalah pembinaan disiplin kerja, pembinaan karir, pembinaan etika profesi dan perilaku profesional. Metode pengumpulan data menggunakan kuesioner. Analisis data menggunakan analisis regresi berganda. Hasil penelitian menunjukkan pembinaan disiplin kerja, pembinaan karir, pembinaan etika profesi berdampak positif terhadap perilaku profesional tenaga kependidikan Sedangkan dari hasil analisis deskriptif persentase tampak bahwa rata-rata pembinaan disiplin kerja, pembinaan karir, pembinaan etika profesi dan perilaku profesional termasuk kategori cukup.
\end{abstract}

JEL Classification: M0 , M5, M54

\begin{tabular}{lr}
\hline Alamat korespondensi : & ISSN \\
Gedung C6 Lantai 2 FE UNNES & $2086-0668$ (cetak) \\
Kampus Sekaran, Gunungpati, Semarang, 50229 & $2337-5434$ (online) \\
Email : ketuts52@gmail.com
\end{tabular}




\section{INTRODUCTION}

Building character and realizing the professional behavior is a shared responsibility of the civil servants and leaders of the organization. Civil Servant called PNS in Indonesia must have knowledge, skills, and abilities with different improvisation but is able to present excellent service. While the leaders of the organization must be able to position, appreciate and treat the available human resources so that they are able to show professional behavior as expected. Therefore, it is the duty and obligation for the leaders of the organization to conduct a development so that employees who have different potential, characteristics, desires, hopes and aspirations can be directed into the behavior of a professional organization (Tjiptoherijanto, 2012).

Professional behavior is the behavior shown by employees in work supported by the knowledge, skills, motivation and high confidence (Widhyarto, 2008). Professional behavior requires three things, they are: (1) development of work discipline; (2) career development and (3) development of profession ethics. The aim is that civil servants are able to be professional in providing excellent service to the community.

It is also confirmed implicitly in the explanation of the Act that the development system which is done in a planned, systematic, and integrated way through the hosting organization of personnel management will influence employee behavior (Saeed et al., 2013). If an employee has a positive and professional behavior, it is expected that at the end, performance of employees also increase. Champathes (2006) stated that development is the best way to improve employee performance

The work discipline development is developing the obedience, loyalty and norms adopted in carrying out the work (Chirasa, 2013). Furthermore, Soss et al. (2011) stated that discipline is a training to enforce the rules of the organization. The research of Beyer and Trice (2007) concluded that employees discipline gave the significant influence toward the performance through attitude changes and work behavior.

Employees' career development is a systematic step which is done by the Head of an organization in preparing his employee's throught the stage of his career well (Noe and Hollenbeck, 2008). The career development can be done by either an individual or an organization. The research of Barneet and Bradly (2007), concluded that organizational support for career development influenced directly toward employees career satisfaction so employees will perform more professional in his job. Career development like a personal training. It is a necessity in the workplace. Without it, employees don't have an organization grasp on their duties (Elnaga \& Imran, 2013).

Profession ethics development is the Organization Head's effort so the employees can perform their duties based on the values or norms of the profession (Keraf, 2004). Profession ethics in the form of norms or principles are accepted by a group as a daily behavior foundation. The profession ethics which belong to the employees in performing their duties can improve their behavior to behave professionally.

The empirical data showed a phenomenon that Unnes's employee's professional behavior is not seen as it is expected. It can be seen from the intrinsic motivation indicators in performing the duties that the employees are relaxed, less creative in using the working time, and not confident in performing the jobs so the job results are not maximum. Hence, the problem in this study is how the impact of work discipline development, career development and profession ethics toward the professional behavior of educational staff? While the objective of the study is analyzing the impact so that the leaders gain input to take a policy in fostering employee.

Judge and Kammeyer-Muller (2012) stated that the behavior is essentially the product of a mental attitude or realization of any decision taken by the mental attitude of the person concerned. Then Widhyharto (2008), says that the behavior is an activity that has been done or intention that has been realized in the form of 
behavior that appears. According Shahab and Nisa (2014), there are three things that need to be considered by the leaders if they are going to predict the behavior of an employee, namely: (1) the employee's behavior which is not the same as the goals of the organization; (2) the behavior of employees which is not directed to organizational goals, and (3) the behavior of employees which is directed to organizational goals.

Creation of ideal behavior is based on the idea that the interests of the individual and organizational interests can be harmonized in order to achieve the goals of the organization that is to improve performance and excellent service. Professional behavior (professionalism) is reliability in performing the tasks that can be run with high quality, timely manner, carefully through the procedure that has been set.

The formation of professional behavior requires specialized knowledge and skills that are made through education and training as an instrument for updates. Therefore, the assumption that professionalism can emerge through the suggestion is not true, because the nature of professionalism requires a result pursuit so we are demanded to always do quality improvement. Professionalism also requires seriousness and thoroughness of work that can only be gained through experience and habituationconditioning.

Furthermore, the nature of professionalism demands persistence and optimism until the results achieved. Then professionalism requires high integrity and requires unanimity thoughts and actions so that the effectiveness of the work becomes high. Based on the characteristics of the professionalism demonstrated above, it is not that easy for someone to behave professionally because he must have certain competencies that support his performance.

Competence is the principal characteristic of a person associated with the performance which is effective or superior in the particular job in accordance with predetermined criteria. Principal characteristic has a very deep meaning and is something that is inherent on the indi- vidual. Noe and Hollenbeck (2008), mention the components of professional competence: 1) specialist competence that is knowledge and technical skills, ability to organize and handle the problem; 2) the individual's competency that is initiative, motivation, creative and reliable. Thereby, it can be concluded that professional behavior is behavior shown by employees in working with high quality, because it is supported by the knowledge, skills, motivation and high confidence.

Development of work discipline is very important because it comes from the view that there is no perfect man. Discipline development starts from an understanding of the discipline itself. Discipline is a form of self-control of employees in the implementation of an organization. Further, discipline is a form of training in order to enforce the rules of the organization.

Van der Bank et al. (2008), said the discipline of work is an attitude of respect, appreciate, obedient and adhere to the regulations applied and ready to accept sanctions if the employees violate their duties and responsibilities. The creation and establishment of discipline can be done through a process starting from a set of behaviors that indicate the values of obedience, loyalty and norms adopted in carrying out the work.

Discipline can be developed formally through training and development of the discipline, as in the work always appreciate the time, effort and expense. Work discipline can also be implanted through exemplary leadership or role models for their employees. Good discipline is derived from self-awareness not compulsion. Discipline that emerges from self-awareness will have a positive impact on the execution of the work. However, discipline development still has an important meaning in order that the potential that comes from oneself is not contaminated by the behavior of superiors and subordinates who are not good. Discipline can create better conditions for the organization because all activities can be done effectively and efficiently.

Van der Bank et al. (2008), also stated that in realizing discipline, there is a need for 
fostering employee discipline that can be done through some development steps such as; the creation of regulations and rules of conduct that must be done, create and provide sanctions for violators of discipline, conduct discipline development through discipline training continuously. Employee's discipline needs to be developed and enforced.

The targets of development are all employees in the organization so that they obey all signs system rules and procedures that have been determined. Thereby, discipline development may influence employee's behavior patterns in a variety of activities to achieve the expected goals. Frequency of development is often done will be able to encourage a change in behavior, attitudes and moral ethics of the employees so that they have a high responsibility to obey the rules that have been set.

Beyer and Trice (2007), stated that employee discipline has a significant effect on performance through changes in attitudes and work behavior. While professional behavior is an attitude, mindset and behavior of employees supported by the knowledge, skills and abilities in accordance with the profession in order to support the success of the employee in accordance with the objectives of the organization. Discipline development done by the organization can direct the behavior of every employee. Widhyharto (2008), concluded employee discipline will encourage professional behavior in working. Based on the background above, the hypothesis is:

H1: The work discipline development gives positive influence toward employees' professional behavior.

Furthermore, a career in the life of the organization, according to Noe and Hollenbeck (2008) can be viewed through several ways: (1) a series of positions in the job, for example, in a faculty there is a position of assistant, lecturer, professor; (2) the context of the movement or mobility within the organization, for example, an engineering graduate begins his career as a technic staff. Employee career development is a systematic step done by the leader of an organization in preparing employees to be able pass their career stages well.

The success parameter of an employee in pursuing career is varied. The difference is the result of a person's level of satisfaction which is also different. Career satisfaction is very dependent on development policies implemented by the leaders of the organization (Barnett \& Bradley, 2007). An understanding of the factors that need to be considered in career development such as; fair treatment, direct care of supervisor, information on promotional opportunities and career satisfaction level will allow personnel part to have active role in planning the career of the employees. A possible way to do is through clear career development systems to help in exploring the potential and career development of employees in order to obtain career satisfaction.

Career of an employee needs to be planned and developed through an individual and organizational path. In human resource management, career planning is intended to identify the desires, aspirations and career opportunities of individuals who subsequently implemented in the human resource development program to support the career. The process of career planning is the responsibility of the individual and the organization. Individuals should identify their aspirations and abilities then through evaluation and counseling to understand the desire in training and development.

Meanwhile, organizations identify the desires and the opportunity to plan and convince the staffs who need information and estimate training and development. Therefore, related to career planning responsibilities, then Antoniu (2010) stated that career planning must link the individual needs and aspiration with organizational needs and opportunities, evaluating, advising and informing its staff on career planing, individual development effors with training and development programs.

Thus the career development goal is to assist in the achievement of individual and organizational goals through planning and career development (Monis \& Sreedhara, 2011). In- 
Ketut Sudarma / Professional Behavior Based on the Employees...

dividual career can be developed through education both formal and non-formal education. Improving education can be done through the efforts of their own at their own cost or seek scholarships, as well as the help from the organization to undertake the cost of education through grants from the budget of the organization. While career development through the organization can be done through employee participation in training relevant to their main tasks so that they have the technical capability to perform the work.

Nowadays there is a new paradigm in career development in which career development that is traditional is considered to be insufficiently flexible to meet the needs of the organization and employees. Career development responsibilities change from organization to the employees' hands individually so that career competence becomes very important. Thus the career development can be more varied. It has an aim that the employee will able to plan a career path to take responsibility for the work in order to improve performance. However, the organizational support in employees' career development is still needed in order to achieve career satisfaction.

Ideally, an employee's career should have a continuous increase year by year. Therefore, it is the duty of leaders to foster by providing a help so that each employee can develop the ability to get a promotion chance in the future, so there will be some changes in employee's behavior. Research of Joo and Ready (2012), concluded that organizational support for career development directly influence career satisfaction so that employees will behave in a more professional way. Meanwhile, research of Gunz and Jalland (2002) stated that effective career management influences the work outcome. Based on the previous analysis, the hypothesis is:

$\mathrm{H} 2$ : The career development gives positive influence toward employees' professional behavior

In connection with the profession ethics, Ladi (2008) said that profession ethics is a good habit or regulations accepted and obeyed by the employees, subsequently settles into normative. Every profession generally has a code of profession conduct in the form of norms or principles accepted by a certain group as a behavior base everyday at work and in the community. Therefore the ethical values of a group is expected to be the values that govern mutual life.

Community groups that have values that form the basis for good relationships with community groups which is written and called by the code of ethics will be a guidance for its members. Society's view becomes sharper when the behavior of some members of the profession who are not based on the values of the community that has been agreed as set out in the code of profession conduct. It will result in a drop of ethics in the profession.

For example, in the law profession recognized the existence of the Mafia, also in the medical profession with the establishment of a specialist super clinic in the extravagant area so that the poor has no access to it, a civil servant becomes pander in PNS recruitment. These examples constitute a violation of the code of profession conduct and on the violations may be double penalized, both based on the code of conduct and regulation of crime. Thus through the code of profession conduct, professional groups are expected to behave in accordance with the values and rules of the profession.

According to Keraf (2004), there are four principles of profession ethics, namely: (1) the principle of responsibility, is a fundamental principle for the professional group. A professional should be responsible for the execution of the work and results; (2) the principle of justice, especially in their profession demands that a professional may not discriminate against any person or provide the same service to everyone, regardless of status, position, or social status in community; (3) the principle of autonomy, which gives the freedom to develop his profession with a wide range of innovation and creativity that is useful for the development of the profession and the public interest and (4) the principle of moral integrity, is the professional 
guidance of themselves that in carrying out their profession will not damage the good name, image and dignity of the profession.

Development of profession ethics is an attempt of the leaders of the organization which is carried out systematically, and continuously so that employees in performing their duties are always based on values or norms of profession. Professional employees are able to work and act through careful and correct consideration, can distinguish which one is ethically permissible and that should not be done. Ingsih (2011), concluded that the profession ethics of employees gives spirit in performing their duties so they can behave professionally through high work ethos to obtain satisfactory work. Based on the above analysis, the hypothesis is:

H3: The profession ethics development gives positive influence toward the employees' behavior.

\section{METODE}

The population of this study was all Unnes education personnel, who do not have structural positions. The samples were set of 50 people. The sampling technique used was proportional random sampling, because the population was composed of rank or class rank. Further, research variables consisted of the development of work discipline with the indicators; the creation of regulations and rules of conduct that must be done, create and provide sanctions for violators of discipline, conduct discipline development through continuous training.

Then the career development with the indicators; fair treatment in a career, direct caring from supervisor, information of promotion opportunities, the level of employee's satisfaction on career and self-capability development. Next is the profession ethics development with the indicators; responsibility principle, the principle of justice, the principle of autonomy and the principle of moral integrity. The last one is the employees' professional behavior with the indicators; showing the knowledge, skills, motivation and confidence.
Methods of collecting data used are questionnaire. This method is the main way to collect data, using a Likert scale, with five answers for this study is a perception research. Interview method was conducted on certain parties as a complementary method of questionnaires. While the data analysis method used was percentage descriptive analysis, to find out the condition of work discipline development, career development, profession ethics development, and the development of employee's professional behavior, and multiple regression analysis to determine the effect among variables. The formula used is:

$\mathrm{Y}=\mathrm{a}+\mathrm{b} 1 \mathrm{X} 1+\mathrm{b} 2 \mathrm{X} 2+\mathrm{b} 3 \mathrm{X} 3$ (Ferdinand, 2006).

\section{RESULT AND DISCUSSION}

Descriptive analysis shows the average of work discipline development, career development, profession ethics development and professional behavior is good enough. Then the multiple regression analysis was done to determine the impact of work discipline development variable (X1), career development (X2), and profession development (X3) toward professional behavior $(\mathrm{Y})$. The multiple regression analysis can be explained through the results of data analysis using SPSS which are shown on the coefficients results in Table 1. Based on the table above, it can be arranged a regression equation as follows:

$$
\mathrm{Y}=12.680+0.323 \mathrm{X} 1+0.337 \mathrm{X} 2+0.190 \mathrm{X} 3
$$

The result of the calculation (X1 on $\mathrm{Y}$ ) using SPSS as shown in Table 1, indicates that the value of $p(\mathrm{sig})=0.005$, so that $\mathrm{p}(\mathrm{sig})(0.005$ $<0.05)$. In conclusion $\mathrm{Ho}$ is rejected and $\mathrm{Ha}(\mathrm{H} 1)$ is supported. This means that the development of work discipline gives positive impact towards the professional behavior of educational staff. Furthermore, based on the calculation of (X2 on $\mathrm{Y}$ ) shows the results of the value of $\mathrm{p}(\mathrm{sig})=0.008$, so that $\mathrm{p}(\mathrm{sig})(0.008<0.05)$, then the conclusion $\mathrm{Ho}$ is rejected and $\mathrm{Ha}(\mathrm{H} 2)$ is supported. This means that career development gives positive im- 
Ketut Sudarma / Professional Behavior Based on the Employees...

pact to the professional behavior of educational staff. The next calculation (X3 on Y) shows the results of the value of $\mathrm{p}(\mathrm{sig})=0.040$, so that $\mathrm{p}$ (sig) $(0.040<0.05)$. Thus Ho is rejected and $\mathrm{Ha}$ (3) is supported. This means that the development of profession ethics gives positive impact on the professional behavior of educational staff. Furthermore, the impact is partially shown by the percentage calculation which can be explained byusing Table 2 .

According to Table 2 above, it indicates that the partial value of the work discipline development variable (X1) towards professional behavior (Y) equals to 0.395 , so the partial determination $\left(\mathrm{r}^{2}\right)$ amounted to $15.60 \%$. While the impact of career development (X2) on professional behavior (Y) equals to 0.330 , so the partial determination $\left(\mathrm{r}^{2}\right)$ amounted to $10.89 \%$. Next is the impact of profession ethics development (X3) towards professional behavior $(\mathrm{Y})$ of 0.298 , so the partial determination $\left(\mathrm{r}^{2}\right) \hat{\mathrm{A}}$ of $8.88 \%$. Thus it can be seen that the partial de- velopment of work discipline (X1) towards the professional behavior $(\mathrm{Y})$ gives the greatest impact.

The results of hypothesis testing ( $\mathrm{H} 1)$, shows that there is positive impact on the development of work discipline towards the professional behavior of educational staff. The results are consistent with the conclusion of Widhyharto (2008), that discipline development will improve professional behavior. It is also supported by the findings of Beyer and Trice (2007), that employees' discipline has a significant influence on the performance through changes in attitudes and work behavior.

While according to the results of the percentage descriptive, work discipline development belongs to good enough. This means that the development of work discipline has not run optimally. Aspect that has not been good is on the socialization aspect of the disciplinary rules where socialization is not done periodically so that there are many employees who do not

Table 1. Calculation for Hypotheses Testing

\section{Coefficients $^{\text {a }}$}

\begin{tabular}{|c|c|c|c|c|c|}
\hline \multirow{2}{*}{$\begin{array}{l}\text { Model } \\
\text { B }\end{array}$} & \multicolumn{2}{|c|}{$\begin{array}{c}\text { Unstandardized } \\
\text { Coefficients }\end{array}$} & \multirow[t]{2}{*}{$\begin{array}{c}\text { Standardized } \\
\text { Coefficients }\end{array}$} & \multirow[t]{2}{*}{$\mathbf{T}$} & \multirow[t]{2}{*}{ Sig. } \\
\hline & Std. Error & Beta & & & \\
\hline (Constant) & 12,680 & 2,542 & & 4.987 & .000 \\
\hline DISCIPLINE & .323 & .111 & .399 & 2.917 & .005 \\
\hline CAREER & .337 & .198 & 253 & 1.391 & .008 \\
\hline ETHICS & .190 & .090 & .280 & 2.119 & .040 \\
\hline
\end{tabular}

a.Dependent Variable: BEHAVIOR

Table 2. Calculation of Partial Impact

Coefficients $^{\text {a }}$

\begin{tabular}{|c|c|c|c|c|c|c|c|}
\hline \multirow{2}{*}{$\begin{array}{l}\text { Model } \\
\text { B }\end{array}$} & \multicolumn{2}{|c|}{$\begin{array}{c}\text { Unstandardized } \\
\text { Coefficients } \\
\end{array}$} & \multirow[t]{2}{*}{$\begin{array}{c}\text { Standardized } \\
\text { Coefficients } \\
\end{array}$} & \multirow[t]{2}{*}{$\mathbf{T}$} & \multirow{2}{*}{$\begin{array}{l}\text { Sig. } \\
\text { Zero- } \\
\text { order }\end{array}$} & \multicolumn{2}{|c|}{ Correlations } \\
\hline & Std. Error & Beta & & & & Partial & Part \\
\hline (Constant) & 12,680 & 2,542 & & 4.987 & .000 & & \\
\hline DISCIPLINE & .323 & .111 & .399 & 2.917 & .005 & .459 & $.395 \quad .363$ \\
\hline CAREER & .337 & .198 & 253 & 1.391 & .008 & .250 & $.330 \quad .284$ \\
\hline ETHICS & .190 & .090 & .280 & 2.119 & .040 & .396 & $.298 \quad .264$ \\
\hline
\end{tabular}

a. Dependent Variable: BEHAVIOR 
know what to do and what not to do. Continuous socialization of disciplinary rules will provide an understanding of the rights and obligations of employees as well as the restrictions.

In addition, employees also perceive that patterns of discipline development and training conducted by the employers/organizations have not been good. This is understandable because the pattern of discipline development is not clear and discipline training which is done through planting habits, such as work on time, participation in the ceremonies are not accompanied by strict sanctions. The application of sanctions is important because work discipline is respecting, valuing, submissive and obedient to the regulations applied and ready to accept sanctions if the employee violate the duties and authorities (Van der Bank et al., 2008).

Further, the results of hypothesis testing (H2) show that there is a positive impact of the career development on the professional behavior of the educational staff. It means that the higher career development, the better employees' professional behavior. The results of this study are in accordance with the findings of Adekola (2011), that the career development has positive influence on career satisfaction to realize a professional behavior. While from the percentage descriptive analysis, it can be seen that the career development belongs to quite good category, this means career development is notmaximum yet. Aspect which belongs to less good appears on the clarity of career development systems. Employees do not understand about the career path that must be passed either through individual and organizational lines.

Monis and Sreedhara (2011), says that there are some career development system components include: (1) self-assessment tools (eg. career planning workshop, career workbooks); (2) individual counseling; (3) information services (eg. Job posting system, skills inventory, career path, career resource centers and other communication formats); (4) the initial work program (eg. anticipatory socialization program, realistic recruitment, employee orienta- tion program); (5) organizational assessment program (assessment centers, psychological testing, succession planning) and (6) developmental program (eg. job rotation programs, in-house training, tuition-refund plans, monitoring).

Noe and Hollenbeck (2008), said that nowadays there is a paradigm shift (concept) in the career system in which traditional career system is considered less flexible to meet the needs of the organization. The new paradigm is based on the concept of protean career, which is a career that often changes grounded on the changes in interest, ability and value of a person as well as changes in the work environment. Compared to traditional career, in protean career employees take greater responsibility in the management of their career. Therefore the role of the organization is to facilitate employees to be able pass the career path that has been planned.

Another aspect which is perceived by the employee to be unmaximum is promotion. Promotion should be done in transparent, fair and objective. The lack of transparency in promotion can be seen from the promotion procedure and the results of the selection which has not been published openly. This is understandable because the standards used to conduct the promotion is unclear. Career is the mobility of employees within an organization ranging from recruitment, appointment to be an employee, up to retire in a series of ranks and positions in its path.

Therefore, every employee has an equal chance in the promotion program provided as long as they meet the specified requirements. Objective promotion will encourage career satisfaction so that it assists in the achievement of individual and organizational goals. If employees feel their career satisfaction, it will have an impact on the professional behavior of employees, where employees will always try to improve the knowledge, skills, motivation and confidence.

Furthermore, the results of hypothesis testing (H3) showed that there is a positive impact on the development of profession ethics on the professional behavior of educational staff. 
Ketut Sudarma / Professional Behavior Based on the Employees...

It means that the higher profession ethics development, the better employees' professional behavior. The results are consistent with the opinion of Sudarma (2012), that the ethics of the profession will be able to encourage a high work ethic so that employees demonstrate professional behavior. The positive effect gives a sense of profession ethics development which is done better will have an impact on the attitude of the professional behavior of employees so that employees have the commitment and pride as an employee.

Employees who have a strong commitment will always hold the principle of professionalism in the form of responsibility, integrity, and providing excellent service based on the principles of transparency and fairness. Results showed that the contribution of profession ethics development is smaller than the work discipline development and career development varibales. This indicates that the result of the work discipline and career development will have an impact on the professional behavior of employees.

This situation can be understood as professional behavior can not realized without starting it from the attitude of discipline in carrying out the work which is further supported by career satisfaction. Profession ethics or code of ethics in carrying out their daily work should be owned by every employee, as a code of conduct can be described as the directions (guide) so that employees can behave well so will be respected, appreciated and won the trust of the community. Through public trust, it will then generate pride of the profession so that every employee tries to prevent behavior that may defame corps or organization. Things to note that the code of ethics is the criteria of professionalism. It gives meaning that a group of people who consider themselves as professional people are not eligible if they have not implemented the profession code of ethics correctly.

Meanwhile, from the percentage descriptive analysis, it appears that the profession ethics development belongs to quite good, means that the profession ethics development has not been maximum yet. This can be seen on the conformity of the act with the profession ethics values. This is understandable because there are still many educational staff who do not have a high responsibility in carrying out their duties as a result of lowlevels of education (high school graduates are still many) so that an understanding of profession ethics is not good yet.

Development of profession ethics is important in order to realize honest, clean, dignified and responsible people in their involvement in developing the organization (Keraf, 2004). Development of profession ethics which is sustainable and targeted will have a positive impact on the professional behavior of employees in order to achieve organizational goals. This finding is strengthen by Noe and Hollenbeck (2008), Keraf (2004) as well as the findings of Rezaean et al. (2012), so that the employee's development which is done continuously and planned well will be able to improve professional behavior.

\section{CONCLUSION AND RECOMMENDATION}

Work discipline development, career development and profession ethics development have a positive impact on the professional behavior of educational staffsl. Work discipline development has the greatest impact, followed by career development and profession ethics development. This situation shows that the work discipline development needs to be supported by career development and profession ethics development continously in order that professional behavior can be realized. Therefore, the better the work discipline development, the career development gives more career satisfaction and the profession ethics goes well, then the professional behavior will be the better to maximum performance.

Managerial implications of this research is that it requires the work discipline development through the socialization of discipline rules periodically, so that the educational staffs really understand the disciplinary rules that must be obeyed. The pattern of the development should 
be clear through the discipline trainingby doing habituation-conditioning such as be punctual in attending meetings, ceremonies, sports, arts and other activities. This activity would have to be monitored continuously and those who do not discipline needs to be fostered through verbal and written warning. For those who commit major violations, the leader must impose sanctions (punishment), in the form of administrative sanctions in accordance with applicable regulations.

Career development also needs to be sustainably done, because the career development will encourage career satisfaction. Therefore, career development through the organization needs to be considered by the leaders. Procedures and mechanisms for the promotion of structural positions should be submitted transparently and objectively. Then the profession ethics development can be improved through the development to realize honest and responsible people. In this case, it needs the good example of the leader that can be used as an example in working life and in the implementation of the organization.

\section{REFERENCES}

Adekola, B. 2011. Career Planning and Career Management as Correlates for Career Development and Job Satisfaction a Case Study of Nigerian Bank Employees. Australian Journal of Business and Management Research. 1 (2): 100-113.

Antoniu, E. 2010. Career Planning Process and Its Role in Human. Resources Development. Journal Annual of Economic. 10 (2): 13-22.

Barnett, B. R \& Bradley. 2007. The Impact of Organizational Support for Career Development and Career Satisfaction. Career Development International Journal. 12 (7): 617-635.

Beyer, J. M \& Trice, H. M. 2007. A Field Study of the Use and Perceived Effects of Discipline in Work Performance. Academy of Management Journal. 27 (4): 743-764.

Champathes, M. R. 2006. Coaching for performance improvement: The coach model. Development and Learning in Organization Journal. 20 (2): 5-21.
Chirasa, V. 2013. Management of Discipline for Good Performance: A theoretical Perspective. Online Journal of Social Sciences Research. 2 (7): 214-219.

Elnaga, A \& Imran, A. 2013. The Effect of Training on Employee Performance. European Journal of Business and Management. 5 (4): 137-148.

Ferdinand, A. 2014. Metode Penelitian Manajemen Edisi 5. Semarang: Badan Penerbit UNDIP.

Gunz, H. P \& Jalland. 2002. Managerial career and Business Strategis. Academy of Management Journal. 33: 54-85.

Ingsih, K. 2011. Menerapkan Etos Kerja Profesional Dalam Meningkatkan Kinerja. Prosiding Seminar Nasional Teknologi Informasi \& Komunikasi Terapan.

Keraf, A. S. 2004. Etika Bisnis Tuntutan dan Relevansinya. Jakarta: Kanisius.

Ladi, S. 2008. Good Governance and Public Administration Reform in the Black Sea Economic Cooperation (BSEC) Member States. Athens: International Centre for Black Sea Studies.

Monis, S. H \& Sreedhara, T. N. 2011. Employee Satisfaction with Career Development Practice: A Comparative Study of Indian and Foreign MNC BPO Firm. Journal of Arts Science and Commerce. 11 (1): 110-123.

Noe, R. A \& Hollenback. 2008. Human Resources Management: Gaining a Competitive Advantage. Illnois: Austen Press.

Joo, Baek-Kyoo (Brian) \& Ready, K. J. 2012. The Influences of Proactive Personality, Performance Goal Orientation, Organizational Learning Culture, and Leader Member Exchange Quality. Career Development International. 17 (3): 276-295.

Judge, T. A \& Kammeyer-Mueller, J. D. 2012. Job Attitudes. The Annual Review of Psychology. 63: 341-67.

Rezaean, A., Hatami, S \& Dastar, H. 2012. Relationship between Career Management and Career Satisfaction. Iranian Journal of Military Medicine. 13 (4): 217-221.

Saeed, R., Shakeel, M \& Lodhi, R. N. 2013. Ethical Behavior and Employees Job Performance in Education Sector of Pakistan. Middle-East Journal of Scientific Research. 18 (4): 524-529.

Shahab, M. A \& Nisa, I. 2014. The Influence of Leadership and Work Attitudes towards Job Satisfaction and Performance of Employee. International Journal of Managerial Studies and Research. 2 (5): 69-77. 
Ketut Sudarma / Professional Behavior Based on the Employees...

Soss, J., Fording, R \& Schram, S. F. 2011. The Organization of Discipline: From Performance Management to Perversity and Punishment. Journal of Public Administration Research and Theory. 21 (2): i203-i232.

Sudarma, K. 2012.MencapaiSumberDaya Manusia Unggul (Analisis Kinerja dan Kualitas Pelayanan). Jurnal Dinamika Manajemen. 3 (1): 77-85.

Tjiptoherijanto, P. 2012. Civil Service Reform in the Philippines: Building Strong Governance. Working Pa- per in Economics and Business. 2 (2): 1-10.

Van der Bank, L., Engelbrecht, A \& Strumpher, J. 2008. Perceived Fairness of Disciplinary Procedures in the Public Service Sector: An Exploratory Study. Journal of Human Resource Management. 6 (2): 1-8.

Widhyharto, S. D. 2008. Menakar Perilaku Profesional Dalam Rangka Meningkatkan Kinerja Aparatur Birokrasi. Jurnal Kebijakan dan Manajemen PNS. 2. 